\title{
Successful under-planting of red oak and black cherry in early-successional deciduous shelterwoods of North America
}

\author{
Alain PAQUeTTE*, André Bouchard, Alain Cogliastro \\ Institut de recherche en biologie végétale (IRBV), Groupe de recherche en écologie forestière interuniversitaire (GREFi), Université de Montréal, \\ 4101 rue Sherbrooke Est, Montréal, Québec, Canada, H1X 2B2
}

(Received 28 February 2006; accepted 12 May 2006)

\begin{abstract}
Underplanting early-successional forest stands with red oak and black cherry was tested as a way of improving productivity on abandoned agricultural land of North American temperate deciduous forests. A partial release treatment was applied during the third growing season and compared to a control. The growth increment after six years is analyzed with respect to treatment and competition layers. Although the release treatment reduced competition at all vegetation layers, growth was mostly determined by the density of the upper layer. Deer herbivory was not increased by the release. The release treatment succeeded in significantly increasing available light for the duration of the study, while the understory recovered quickly. Planted trees, particularly red oak, responded well to the release treatment. Results substantiate the need for dynamic silviculture in sensitive, rural landscapes, where conservation of forest structure is important.
\end{abstract}

under-planting / light / early-successional forests / deer herbivory / thinning treatment

Résumé - Plantation sous-couvert de chêne rouge et cerisier tardif en forêt décidue pionnière d'Amérique du Nord. Des chênes rouges et cerisiers tardifs ont été introduits sous couvert de jeunes peuplements d'origine agricole dans une étude visant l'amélioration de la productivité de peuplements pionniers de la forêt décidue tempérée d'Amérique du Nord. Un dégagement partiel appliqué au cours de la troisième saison de croissance est comparé à un témoin. La croissance après six ans est analysée en fonction du traitement et des strates de compétition. Alors que le traitement avait significativement diminué la compétition à tous les niveaux, la croissance était surtout fonction de la densité de la strate supérieure. L'herbivorie par le cerf n'a pas été augmentée par le dégagement. Le traitement de dégagement a significativement accru la lumière disponible pour toute la durée de l'étude, alors que le sous-étage s'est reconstitué rapidement. Les plants, particulièrement les chênes rouges, ont bien répondu au dégagement. Les résultats supportent une sylviculture plus dynamique dans les paysages ruraux sensibles, où la conservation des structures forestières est importante.

plantation sous-couvert / lumière / forêt pionnière / herbivorie par le cerf / traitement de dégagement

\section{INTRODUCTION}

Underplanting while preserving part of the existing vegetation to serve as shelterwood has been proposed as a means of increasing valuable timber production in impoverished forest environments $[22,40]$. The present study tested the method under common but poorly understood young pioneer stands within impoverished rural landscapes. The North American temperate deciduous forest has been highly transformed by human activity over the last four centuries, following European colonization. The forest slowly started to recover during the 20th century due to the reduction of agricultural activities on soils of marginal agricultural value [10,34]. A number of recent studies have focused on vegetation, human disturbance, and reforestation with valuable hardwoods in the southernmost part of the St-Lawrence River Valley in eastern Canada $[6,14,16]$. Some species found in large numbers at the beginning of the colonial period are now rare, while community composition has changed significantly $[9,47]$. Many of these early-successional forest communities show serious

\footnotetext{
*Corresponding author: alain.paquette@gmail.com
}

regeneration problems even after several decades and are still widely negatively perceived $[3,36]$. However, they can be considered as new opportunities to restore the forest to its former productivity [30].

Artificial regeneration under a shelterwood (underplanting) is relatively recent in eastern North America [27]. The technique is based in part on the long experience of American foresters in promoting the establishment of advanced natural regeneration prior to harvesting in fire adapted oak stands [21], and in the boreal forest as an alternative to clearcutting [20]. In Europe it was proposed as a technique for reconstructing forests damaged by the great windthrow of December 1999 [7], for converting even-aged plantation monocultures into mixed or two-storied stands [29], and for promoting natural regeneration [2]. We believe the technique should be successful in impoverished young successional temperate forests in rural landscapes where the standing trees have no commercial value and instead could help promote the establishment of a new cohort of high-value species, a technique which resembles enrichment under-planting in tropical forests $[39,40]$. 
Table I. Summary of site characteristics and silvicultural work.

\begin{tabular}{|c|c|c|}
\hline & St-Chrysostôme & Ste-Clotilde \\
\hline Area & 2.5 ha & 3 ha \\
\hline Soil $(15 \mathrm{~cm})$ & Sandy loam; pH 5.15 & Sandy loam; pH 5.87 \\
\hline \multirow[t]{3}{*}{ Composition } & B. populifolia, O. virginiana & B. populifolia, O. virginiana, \\
\hline & and $U$. americana & F. americana, C. caroliniana \\
\hline & High shrub density & and $U$. americana \\
\hline Basal area $^{\mathrm{a}}$ & $21 \mathrm{~m}^{2} / \mathrm{ha}$ & $16 \mathrm{~m}^{2} / \mathrm{ha}$ \\
\hline Density $^{\mathrm{a}}$ & 6500 stems/ha & 6100 stems/ha \\
\hline Canopy height & $11 \mathrm{~m}$ & $12 \mathrm{~m}$ \\
\hline Origin $^{\mathrm{b}}$ & 1962 & 1962 \\
\hline Preparation & None & Thinning (fall 1997) \\
\hline Planting & \multicolumn{2}{|c|}{ April 28th and 29th 1998; 900/ha $(3 \mathrm{~m} \times 3 \mathrm{~m})$} \\
\hline Release & \multicolumn{2}{|c|}{ Summer $2000 ; 1 \mathrm{~m}$ around planted seedlings } \\
\hline
\end{tabular}

Stand height, composition, density and basal area, as well as soil $\mathrm{pH}$ and texture were evaluated in summer 2000, prior to the release treatment. ${ }^{\text {a }}$ All species DBH $>1 \mathrm{~cm} .{ }^{\mathrm{b}}$ Approximate year of abandonment of agricultural activities (pasture), based on growth ring counts of sampled trees.

The environment created by a shelterwood is a compromise between resource availability (mostly light) on the one hand, and protection from understory competition, herbivory, and climatic extremes on the other [42]. Available light for tree regeneration establishment (natural or artificial) is increased through thinning [17], but not so much as to promote competition by understory shrubs or herbaceous plants $[12,33]$, or climatic stress $[2,31,37]$. These conditions should allow an effective establishment of the trees and their positive reaction to an eventual release $[18,26]$.

Herbivory by white-tailed deer (Odocoileus virginianus) is an increasing problem for natural and artificial regeneration in eastern North America $[23,32]$. It is hypothesized that herbivory, in addition to damages caused by climatic conditions, will increase with the thinning of the stand, whereas a denser shelterwood would better protect the planted trees $[11,18]$.

Little information is available specifically for seedlings planted under young successional forest stands as to (1) the density of canopy retention (shelterwood) and light levels required, (2) the growth rates to expect, (3) the choice of species to use, (4) the effect on herbivory, and (5) the singular and combined effects of competition from above or below. Based on six years of growth, we tested red oak (Quercus rubra L.) and black cherry (Prunus serotina Ehrh.) performance under two levels of shelterwood density.

Although there is quite a large body of literature on natural and artificial regeneration of red oak in north-eastern North America, it deals mostly with poorly regenerated mature oak stands [35]. Moreover, very little data is available concerning black cherry in shelterwood environments. The planted species have a shade tolerance that ranges from intermediate (red oak) [46] to low (black cherry) [38]; red oak is more shade tolerant when young [28]. Marquis [38] mentions that a partial cover is required for optimal establishment of black cherry, but that full sunlight is necessary afterwards to ensure continued growth, which can be vigorous. On average, red oaks in a variety of shelterwood densities (excluding unmanaged control treatments and clear-cuts) reviewed in Paquette et al. [42], grew $10 \mathrm{~cm}$ per year (varying from 4 to $28 \mathrm{~cm}$ ), which is well below the recommended success criterion of at least $30 \mathrm{~cm}$ proposed by Johnson [26].

\section{MATERIALS AND METHODS}

\subsection{Study sites and stand characteristics}

Two sites located in the St-Lawrence River Valley, an important agricultural region in eastern Canada, within the sugar maple - hickory bioclimatic domain [50], were selected for this study. The region has a humid continental climate with mean annual temperatures of $6{ }^{\circ} \mathrm{C}$, and monthly means of $21{ }^{\circ} \mathrm{C}$ in July and $-10{ }^{\circ} \mathrm{C}$ in January. Mean annual total precipitation is $1030 \mathrm{~mm}$ (of which $18 \%$ falls as snow), and is well distributed throughout the year (Environment Canada, climatological normals 1971-2000). Stands at both sites share similar soils (Tab. I) and originate from recent (1962) agricultural abandonment (pasture), which followed extensive deforestation and high grading.

The St-Chrysostôme site $\left(45^{\circ} 09^{\prime} \mathrm{N} ; 73^{\circ} 45^{\prime} \mathrm{W}\right)$ is dominated by grey birch (Betula populifolia Marsh.), which comprises 67\% of the stand's basal area. Hophornbeam (Ostrya virginiana (Mill.) K. Koch) and white elm (Ulmus americana L.) are also present (22\%), but late successional species are almost absent from the canopy and rare in the undergrowth. Tall shrubs (Crataegus spp. and Malus pumila Mill.) are also present and form dense thickets under which regeneration is greatly reduced. A major ice storm (January 1998) seriously damaged the site and most grey birch stems were bent. With a basal area of $21 \mathrm{~m}^{2} /$ ha (all species DBH $>1 \mathrm{~cm}$ ), this site was deemed to be sufficiently open to be under-planted directly in the spring of 1998, without prior site preparation (Tab. I).

The Ste-Clotilde site $\left(45^{\circ} 08^{\prime} \mathrm{N} ; 73^{\circ} 38^{\prime} \mathrm{W}\right)$ is of the same age, and grey birch is still dominant in the upper vegetation layer, but less so than on the St-Chrysostôme site ( $26 \%$ of total basal area) because this species was the primary target of a preparation thinning. It is 


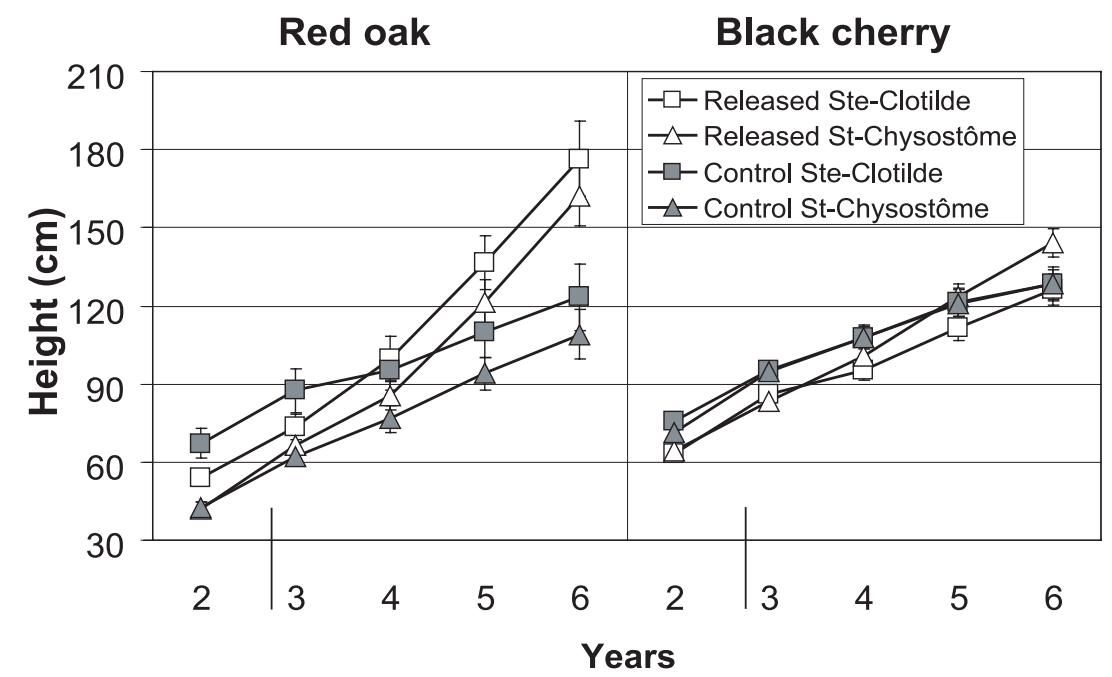

Figure 1. Mean tree height in relation to time since year 2 (1999), site and treatment. Timing of the release (summer of year 3) is represented by a vertical bar. Error bars are \pm standard error (some error bars are smaller than the corresponding symbol).

accompanied by hophornbeam, white ash (Fraxinus americana L.), hornbeam (Carpinus caroliniana Walt.) and white elm (63\%). Shrubs are less abundant, and valuable hardwood regeneration is somewhat greater, but restricted to the vicinity of a few remaining large seed trees pre-dating agricultural abandonment and heavily damaged by the ice storm. The Ste-Clotilde site was prepared during fall 1997 by thinning approximately $30 \%$ of the stand's basal area without creating major openings in the canopy, and primarily targeting early successional species. The residual basal area was $16 \mathrm{~m}^{2} / \mathrm{ha}$, which is lower than that of the St-Chrysostôme site without preparation $\left(21 \mathrm{~m}^{2} / \mathrm{ha}\right)$, with comparable stem densities of over $6000 \mathrm{stems} / \mathrm{ha}$ and average stand height of $11 \mathrm{~m}$ (Tab. I).

\subsection{Under-planting of black cherry and red oak seedlings}

Under-planting was carried out in spring 1998 (hereafter noted as year 1) using one-year-old black cherry and red oak in containers $(340 \mathrm{~mL})$. Mean height and diameter at the root collar for black cherry were $34 \mathrm{~cm}$ and $4 \mathrm{~mm}$, respectively, and $27 \mathrm{~cm}$ and $6 \mathrm{~mm}$ for red oak (nursery data). Black cherries were planted in greater numbers than red oaks on both sites (2:1 at St-Chrysostôme and 6:1 at SteClotilde) due to limited supplies at the nursery. Trees were planted every $3 \mathrm{~m}$, on parallel planting lines spaced at $3 \mathrm{~m}$. Species were distributed on alternate planting lines, according to their respective proportions. Inadequate micro-sites, due in particular to small depressions with drainage problems or fallen trees from the ice storm, were avoided for an approximate final density of 900 trees per ha.

\subsection{Experimental design and treatment}

In early spring of 2000 (year 3) experimental rectangular plots were delineated so as to contain areas with visually homogenous vegetation composition, and scattered over the planted areas. Plots vary from 400 to $600 \mathrm{~m}^{2}$. Eleven were established at the St-Chrysostôme site for a total area of 0.62 ha (25\% of the total planted area), and twelve at the Ste-Clotilde site for a total area of 0.56 ha (19\%). Each site was then separated in two halves along its length to allow replication blocks to account for possible spatial heterogeneity [25]. Plots were then randomly assigned to either "control" or "treatment", ensuring that all four replication blocks (two on each site) contained the four combinations of treatment and species, and that buffers of at least $20 \mathrm{~m}$ were kept between control and treated plots. In the treated plots, all trees and shrubs $(1 \mathrm{~cm}<\mathrm{DBH}<10 \mathrm{~cm})$ were cut within a one meter radius around the planted trees, whereas the herbaceous vegetation and small woody stems $(<1 \mathrm{~cm})$ were cut flush with the ground within a smaller radius $(50 \mathrm{~cm})$, in proportion to their smaller size. Larger trees $(>10 \mathrm{~cm})$ within the same $1 \mathrm{~m}$ radius were devitalized with glyphosate herbicide capsules (E-Z-Ject system, Waynesboro, MS, USA) and left standing to prevent damage to seedlings. The vegetation of control plots was left untouched.

All trees in each plot were inventoried early in the spring of year 3; damaged or diseased trees were excluded, as well as a number of trees with bad drainage microsite conditions that were not identified at the time of plantation. The 593 trees used in the analyses, 149 red oaks and 444 black cherries, are distributed as follows: at St-Chrysostôme, 66 red oaks and 73 black cherries in control plots, 48 and 112, respectively, in released plots, and at Ste-Clotilde 15 red oaks and 139 black cherries as controls, and 20 and 120, respectively, in released plots.

\subsection{Planted tree growth and herbivory}

Herbivory by white-tailed deer still occurred, but was reduced by the application twice annually (May and October), as of year 3, of a deer repellent (Deer-Away, IntAgra Inc., Minneapolis, MN, USA). Deer herbivory was recorded as a semi-continuous variable according to whether it was heavy, particularly on the leader (2), weak or on the lateral shoots $(1)$, or absent $(0)[5,51]$.

Total height and diameter at ground level of planted trees for year 2 was measured in early spring of year 3 (before bud burst) and at the end of growing seasons 3 through 6 . Before the release treatment was applied, black cherries were taller, on average, than were red oaks $(p<0.0001)$ (Fig. 1). Although plots were chosen randomly between 
Table II. Treatment effect on light availability and stand characteristics in year 4 (2001) (means and standard error).

\begin{tabular}{|c|c|c|c|c|}
\hline$\overline{\text { Site }}$ & & Light at $1 \mathrm{~m}(\% \mathrm{PPFD})$ & Basal area $\left(\mathrm{m}^{2} / \mathrm{ha}\right)$ & Density (stems/ha) \\
\hline \multirow{2}{*}{ St-Chrysostôme } & Control & $11(0.9)$ & $20.3(1.0)$ & 7155 (332) \\
\hline & Released & $20(0.6)$ & $15.4(0.9)$ & 3669 (197) \\
\hline \multirow{2}{*}{ Ste-Clotilde } & Control & $9(0.5)$ & $16.2(0.7)$ & $6197(248)$ \\
\hline & Released & $24(1.1)$ & $9.7(0.7)$ & $3750(203)$ \\
\hline ANOVA & d.f. & $F(p>F)$ & $F(p>F)$ & $F(p>F)$ \\
\hline Model & 7 & $62.04(<0.0001)$ & $12.38(<0.0001)$ & $23.33(<0.0001)$ \\
\hline Block $^{\mathrm{a}}$ & 3 & $0.0239(0.9940)$ & $10.07(0.0448)$ & $0.7861(0.5760)$ \\
\hline Treatment & 1 & $25.31(0.0146)$ & $42.13(0.0026)$ & $73.88(0.0015)$ \\
\hline Block $\times$ Treatment ${ }^{\mathrm{a}}$ & 3 & $14.98(<0.0001)$ & $0.9812(0.4012)$ & $1.608(0.1864)$ \\
\hline Whole model $R^{2}(N)$ & & $0.46(517)$ & $0.13(590)$ & $0.22(590)$ \\
\hline
\end{tabular}

Available light and stand characteristics were rank transformed prior to analysis. ${ }^{\text {a }}$ Random effects.

control and treatment groups, control black cherries were taller than those that were to be released $(p<0.0001)$.

\subsection{Competition and light availability}

Inventories of trees and large shrubs around planted trees were done at year 3 before the release treatment in all plots, and repeated at year 4 in the treated plots. DBH of all woody stems (trees and shrubs $>1 \mathrm{~cm}$ ) was recorded within a radius of three meters around each planted tree and basal area values were computed. No significant differences were found in basal area between designated control and release plots before the release treatment, on both sites.

Available light was measured before (year 3) and after the release treatment of planted trees (year 4), and again in years 5 and 6 . Light measures were used as they integrate the effects of all plants around the seedlings and so are accurate descriptors of a seedling's growing environment. They also measure the actual result of the thinning treatment, accounting for prior heterogeneity and possible variability in its application, including the presence of devitalized trees that were left standing. The instantaneous measurement of available light (\%PPFD) was made according to Parent and Messier [43], using two quantum sensors (li-190, LiCor, Lincoln, NE, USA) on a cloudy day (solar disk invisible), between July 1st and August 31st of each year. One sensor was located in a nearby open field as a reference and the other in situ. Light measurements were taken at each seedling location at $50 \mathrm{~cm}$, one and two meters above ground, and finally just above their crown, in the prolongation of the main axis for measurements taken above the crown, and at its margin for lower ones to prevent self-shading.

Because required light measurement conditions (overcast sky) were difficult to obtain within a short period of time for such a large number of measurements (593 trees, at four heights), we limited the first measurements to only those plots which were to receive the release treatment in order to obtain pre-treatment values (year 3). At year 4, especially difficult for light measurements, we measured available light in all plots and for all trees at $1 \mathrm{~m}$, but only on a sample of trees for the other heights. Measurements at all fixed heights $(50 \mathrm{~cm}$, $1 \mathrm{~m}$ and $2 \mathrm{~m}$ ) were taken on all trees at years 5 and 6 . Finally, crown level values were measured at year 6 and were predicted for all other years using linear regressions computed for each year from data at fixed heights from the same site and treatment. Sample sizes are given where appropriate and should be considered when interpreting light measurement results, especially at year 4 where values at $1 \mathrm{~m}$ should be used preferably. We computed an understory density index as a function of the light extinction coefficient of that layer [4] (Eq. (1)):

$$
\text { understory density (UD) }=1-\left(\% \mathrm{PPFD}_{50 \mathrm{~cm}} / \% \mathrm{PPFD}_{200 \mathrm{~cm}}\right) \text {. }
$$

\subsection{Statistical analysis}

The experimental design is composed of four replication blocks (two on each site), two treatments (released and control) and two species. Sites are thus considered random effects [24] and eventual differences between sites, or among them, can be investigated using contrast tests. ANOVA with random effects was used to test (1) the effect of the release treatment on stand characteristics (available light, understory density, basal area and stem density), and (2) the effect of treatment on tree growth. The effect of treatment on herbivory was tested using ordinal logistic fit and likelihood ratio tests. The effect of competition from above (\%PPFD at $2 \mathrm{~m}$ ) and from below (understory density index) on tree growth was tested using multiple regression. Rank transformations were used, where appropriate, to meet assumptions of normality and homoscedasticity in parametric analyses.

\section{RESULTS}

Because the planted trees are relatively close to each other $(3 \mathrm{~m} \times 3 \mathrm{~m})$, the combined effects of individual releases around each of them in the 3rd year of growth in the treated plots were such that they allowed for a significant increase in the range of available light conditions. The light available at one meter above ground rose from $10 \%$ to $22 \%$ on average (Tab. II). This increase in available light is due to a significant reduction in total basal area (24\% at St-Chrysostôme and $40 \%$ at Ste-Clotilde), and stem density (49\% and 39\%, respectively), although the Ste-Clotilde site had a somewhat lesser initial basal area following the preparation cut in 1997 (contrast test - Tab. II). A "Block $\times$ Treatment" interaction was observed for light levels, and is related to a weaker treatment effect in one of St-Chrysostôme's blocks (contrast test). 


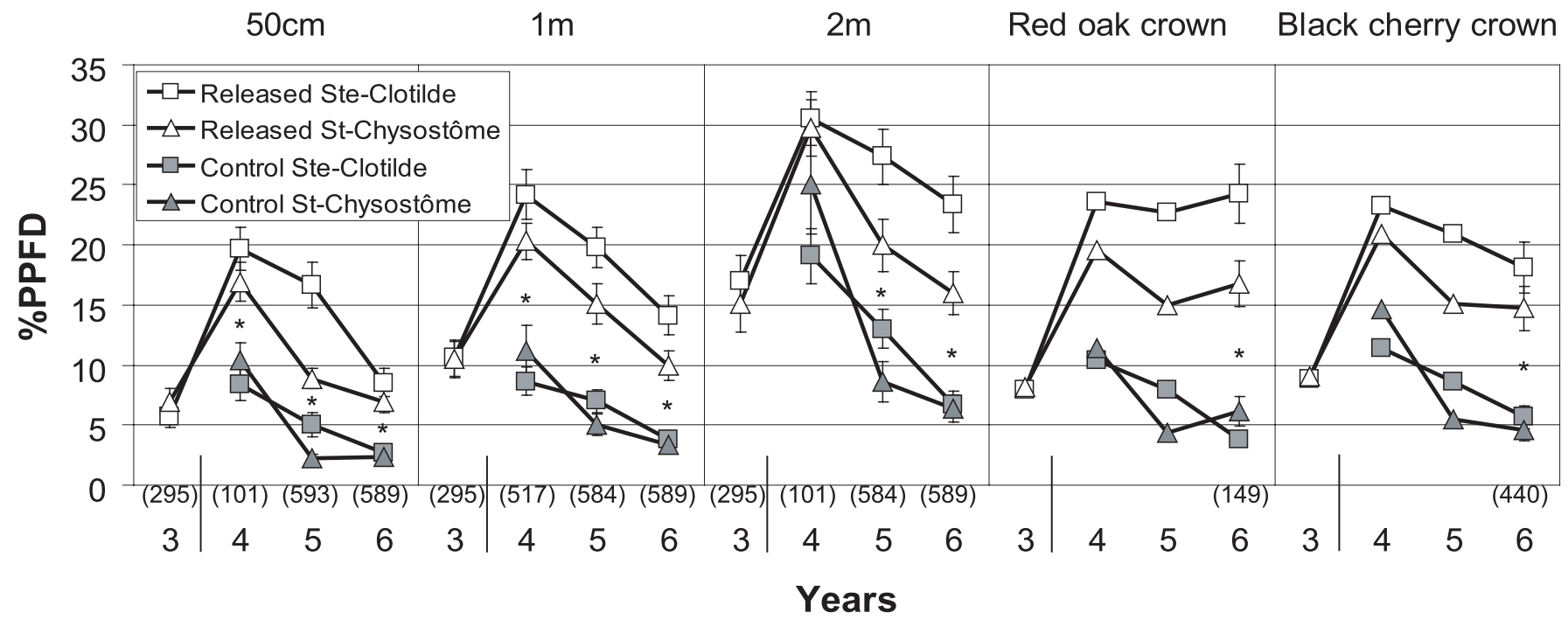

Figure 2. Mean available light (\%PPFD) in relation to time according to site, treatment, and measuring height $(50 \mathrm{~cm}, 1 \mathrm{~m}$ and $2 \mathrm{~m}$ above ground, and just above the crown of planted trees). Timing of the release (summer of year 3) is represented by a vertical bar. Sample size is given between parenthesis. ${ }^{*}$ Significant treatment effects for each year are noted with an asterisk (model as in Tab. II). Error bars are \pm two standard deviations (some error bars are smaller than the corresponding symbol). No error bars or test results are presented for years 3 through 5 at crown level because they are predicted values at mean tree height.

The light available at $50 \mathrm{~cm}, 1 \mathrm{~m}$ and $2 \mathrm{~m}$ above ground increased significantly after the release treatment in treated plots, and with the same intensity at all heights (approximately $12 \%$ points; the non significant result at $2 \mathrm{~m}$ in the 4 th year is due to under-sampling; Fig. 2). Starting in the 4th year, however, available light decreased until in year 6 it reached levels comparable to those prior to the release (Fig. 2). Control plots followed the same trend, with a regular decrease in available light at all measurement heights.

The effect on released trees of both species was observed at their crown, which received more light after the treatment (Fig. 2). Because of their small size in the 3rd year, released red oaks received less light than that available at one meter, but the situation was much improved in the following years as their sustained growth (Fig. 1) kept them at 20\% available light on average. Because they grew more slowly, released black cherries could not maintain the light levels attained at their crown after the release (Fig. 1). In the control plots, light at crown level decreased each year for trees of both species, following the same trend observed at fixed heights, because they did not grow enough to overcome the natural growth and densification of the stands (Fig. 2).

The release treatment strongly increased the mean annual height increment of both species in the last two years at both sites (Tab. III). Increments of 13 to $16 \mathrm{~cm}$ were observed in control red oaks, which is slightly higher than in black cherry under the same conditions $(10 \mathrm{~cm})$. The increment was $38 \mathrm{~cm}$, more than double, for released red oaks, whereas it only increased by 15 to $22 \mathrm{~cm}$ in released black cherries (Tab. III). The effect on diameter growth was even stronger; on average close to six times greater for released red oaks and about half as much for black cherry (Tab. III). Annual increments during the year immediately following the treatment (4th), did not show any significant treatment effect on both species (not shown). The change in growth curves is easily observed for red oak and occurred later, during the 5th growing season (Fig. 1). For black cherry, a change in growth was observed on control trees, which started to show signs of stagnation during the 4th growing season, whereas released trees, which started smaller, overcame the stagnation and maintained a regular but slow growth rate thereafter (Fig. 1). By the end of the experiment, control and released red oaks were on average $112 \mathrm{~cm}$ and $166 \mathrm{~cm}$ tall, respectively, while black cherries were $128 \mathrm{~cm}$ and $134 \mathrm{~cm}$, and released trees had finally reached or overcome the controls (Fig. 1).

The release treatment performed in year 3 targeted all vegetation layers around the seedlings, from the ground up. Its effect on available light was still significant three years later at all heights (Fig. 2; year 6). The treatment effect on understory density (UD), as evaluated by the ratio of the light measured at $50 \mathrm{~cm}$ and that at $2 \mathrm{~m}$ (Eq. (1)), was not as important. By the end of the experiment (year 6), no treatment effect on understory density could be detected (Tab. IV), because that layer had recovered from the release, fueled by the increased light available at higher levels.

Though red oaks seemed to have suffered heavier herbivory in the control plots (Tab. IV), the release treatment had no detectable effect on herbivory, and deer damage did not vary between or among sites.

The range of competition conditions, naturally present and amplified by the treatment, created ideal conditions for testing the single and combined effects of competition from above (available light at $2 \mathrm{~m}$ ) and from below (understory density). Red oak and black cherry responded positively in height and diameter growth to higher light levels above them (Tab. V). Again, as with treatment, the response was stronger for red 
Table III. Treatment effect on mean annual height and diameter increments (standard error) per species (4th to 6th year).

\begin{tabular}{|c|c|c|c|c|c|}
\hline \multirow[t]{2}{*}{ Site } & & \multicolumn{2}{|c|}{ Height increment $(\mathrm{cm})$} & \multicolumn{2}{|c|}{ Diameter increment $(\mathrm{mm})$} \\
\hline & & Red oak & Black cherry & Red oak & Black cherry \\
\hline \multirow[t]{2}{*}{ St-Chrysostôme } & Control & $16(2.9)$ & $10(1.8)$ & $0.5(0.17)$ & $0.4(0.15)$ \\
\hline & Released & $38(3.5)$ & $22(1.6)$ & $2.8(0.36)$ & $1.6(0.16)$ \\
\hline \multirow[t]{2}{*}{ Ste-Clotilde } & Control & $13(4.1)$ & $10(1.8)$ & $0.6(0.23)$ & $0.6(0.14)$ \\
\hline & Released & $38(4.8)$ & $15(1.9)$ & $3.6(0.41)$ & $1.5(0.18)$ \\
\hline ANOVA & d.f. & $p>F^{\mathrm{b}}$ & $p>F$ & $p>F$ & $p>F$ \\
\hline Model & 7 & $<0.0001$ & $<0.0001$ & $<0.0001$ & $<0.0001$ \\
\hline Block $^{\mathrm{a}}$ & 3 & 0.4803 & 0.1777 & 0.3926 & 0.8262 \\
\hline Treatment & 1 & 0.0107 & 0.0239 & 0.0110 & 0.0264 \\
\hline Block $\times$ Treatment ${ }^{\mathrm{a}}$ & 3 & 0.4005 & 0.1021 & 0.0844 & 0.0108 \\
\hline Model $R^{2}(N)$ & & $0.27(147)$ & $0.12(440)$ & $0.43(146)$ & $0.12(440)$ \\
\hline
\end{tabular}

Height and diameter increments were rank transformed prior to analysis. ${ }^{a}$ Random effects. ${ }^{b}$ Only probabilities are given for clarity.

Table IV. Means (standard error) and treatment effect in year 6 on understory density index (Eq. (1)) and herbivory intensity.

\begin{tabular}{|c|c|c|c|c|}
\hline \multirow[t]{2}{*}{$\overline{\text { Site }}$} & & \multirow{2}{*}{$\begin{array}{c}\text { Understory } \\
\text { density index }\end{array}$} & \multicolumn{2}{|c|}{ Herbivory $(\%)^{\mathrm{a}}$} \\
\hline & & & Red oak & Black cherry \\
\hline \multirow[t]{2}{*}{ St-Chrysostôme } & Control & $0.54(0.026)$ & 44 & 10 \\
\hline & Released & $0.50(0.022)$ & 19 & 13 \\
\hline \multirow[t]{2}{*}{ Ste-Clotilde } & Control & $0.54(0.025)$ & 21 & 20 \\
\hline & Released & $0.59(0.019)$ & 10 & 14 \\
\hline Tests & d.f. & $F(p>F)$ & $\operatorname{chi}^{2}\left(p>\operatorname{chi}^{2}\right)$ & $\operatorname{chi}^{2}\left(p>\operatorname{chi}^{2}\right)$ \\
\hline Model & 7 & $2.74(0.0084)$ & $14.2(0.0484)$ & $7.87(0.3442)$ \\
\hline Block $^{b}$ & 3 & $3.14(0.1861)$ & $3.91(0.2710)$ & $3.93(0.2688)$ \\
\hline Treatment & 1 & $0.645(0.4699)$ & $0.042(0.8372)$ & $0.053(0.8160)$ \\
\hline Block $\times$ Treatment ${ }^{b}$ & 3 & $1.46(0.2233)$ & $1.68(0.6417)$ & $4.00(0.2616)$ \\
\hline Model $R^{2}(N)$ & & $0.03(589)$ & 0.07 (148) & $0.02(441)$ \\
\hline
\end{tabular}

ANOVA results are presented for rank transformed understory density index. Herbivory (three classes) is tested using ordinal logistic fit and likelihood ratios. ${ }^{a}$ Classes 1 (weak) and 2 (heavy) of herbivory intensity were combined only for computing percentage of predated trees. ${ }^{\mathrm{b}}$ Random effects.

oak than for black cherry. Competition from below (understory density) had no effect on red oak, while for black cherry better height and diameter growth is also associated with a thicker understory (Tab. V).

\section{DISCUSSION}

\subsection{Light}

The gradual decrease in light availability in treated plots can be explained by the gradual closing of the stands, but it does not seem to be related to the treatment because the same trend is observed in control plots (Fig. 2). It is instead a natural process of densification associated with the aging of these young stands.

The recommended shelterwood level reported in the literature for establishment of red oak under mature stands in north-eastern USA varies, but is often around $60 \%$ of original basal area $[18,26]$. In a recent review of published results from under-planting studies, an optimal intermediate density (40\% to $60 \%$ basal area) was identified for the growth of underplanted trees (mostly red oak) in that region, corresponding to levels of $25 \%$ to $50 \%$ available light [42].

The under-planting experiment we conducted in young shade intolerant hardwood stands had light intensities at one meter above ground in control plots (approximately 10\%), as well as in treated plots (22\%) which would rank our design in the dense shelterwood category. We must go up to two meters above ground, in released plots, to find light intensities greater than $25 \%$, but they decreased to below that level in less than two years (Fig. 2).

\subsection{Growth increments}

Black cherry, an early-successional species, should have responded to the release treatment with greater growth increments than red oak, of intermediate shade tolerance. The opposite results were obtained; red oak reacted more strongly 
Table V. Multiple regression analysis of available light at two meters (\%PPFD $2 \mathrm{~m}$ ) and understory density (UD) effect on red oak and black cherry mean annual height and diameter increments (4th to 6th year).

\begin{tabular}{|c|c|c|c|c|c|}
\hline & & \multicolumn{2}{|c|}{ Height increment } & \multicolumn{2}{|c|}{ Diameter increment } \\
\hline & & Red oak & Black cherry & Red oak & Black cherry \\
\hline Test & d.f. & $p>F^{\mathrm{a}}$ & $p>F$ & $p>F$ & $p>F$ \\
\hline Model & 3 & $<0.0001$ & $<0.0001$ & $<0.0001$ & $<0.0001$ \\
\hline$\% \mathrm{PPFD}_{2 \mathrm{~m}}$ & 1 & $<0.0001$ & $<0.0001$ & $<0.0001$ & $<0.0001$ \\
\hline UD & 1 & 0.0947 & $<0.0001$ & 0.6705 & 0.0265 \\
\hline$\% \mathrm{PPFD}_{2 \mathrm{~m}} \times \mathrm{UD}$ & 1 & 0.5787 & 0.3850 & 0.8286 & 0.0024 \\
\hline Model $R^{2}(N)$ & & $0.45(147)$ & $0.12(436)$ & $0.55(146)$ & $0.13(436)$ \\
\hline
\end{tabular}

Growth increments, available light and UD were rank transformed prior to analysis. See Equation (1) for UD ratio. ${ }^{\text {a }}$ Only probabilities are given for clarity.

to the release than did black cherry (Fig. 1). It is possible that light availability even in treated plots was not sufficiently high for black cherry, never providing the necessary conditions for its optimal growth, which can be substantial. Very little literature exists on this species in spite of its high economic value. With annual height increments of $10 \mathrm{~cm}$ (control) and $18 \mathrm{~cm}$ (treated), black cherry results are within the averages reported in the literature for hardwood species in North America [42].

Our results for released red oaks are nearly four times the average reported, with $38 \mathrm{~cm}$ of mean annual height increment (Tab. III), whereas results from control plots are comparable to the ones recorded for managed shelterwoods. Our results for released red oaks also stand up well to comparison with open field experiments conducted within the same region with the use of herbicides [14,51]. While Kaelke et al. [28] raise doubts about the capacity of red oak to respond effectively to this type of silviculture, due to its alleged low plasticity, the species reacted well to the release treatment applied at the 3rd growing season under a young forest cover of intolerant deciduous species.

\subsection{Competition stratification}

Planted trees with good annual growth were positively associated with a thinner upper layer of vegetation (Tab. V). Although it is generally recognized that growth increases with decreasing competition, few studies have looked at the vertical position of this competition. Lorimer et al. [35] observed that the density of the intermediate layer of vegetation negatively affected the growth and survival of oak seedlings, while understory vegetation competition had no effect. Others found similar results, namely the predominant effect of competition produced by the overstory canopy on that of the lower vegetation layer [1, 11, 15,48]. Grassi and Giannini [19] found strong growth and morphological relations with available light (canopy induced), but none with competing sapling's density. For Brandeis et al. [8] and Spetich et al. [49], growth increased with a decrease in the density of the shelterwood stand and of the understory competition. Although light is not the only factor explaining growth in forest understories (below-ground competition is another important one), it is a good integrator of most competition and resource factors in all but the most nutrient poor or dry conditions [44]. In the present study, it seems clear that within the range of light conditions experienced, the density of the layer above the seedlings is of prime importance in explaining growth of planted red oak and black cherry. The density of the understory did not affect growth of planted red oaks, while a thicker understory, following an increase in light availability at higher levels, was associated with increased growth of black cherry. Both height and diameter growth were increased, pointing to an increase in available light at the top of the seedlings (which would also explain the thicker understory), and possibly better protection from deer browsing (see below), rather than an increased height to diameter ratio following the seedlings adaptation to overcome understory competition (by allocating more resources to height at the expense of diameter growth), as was observed by Cogliastro et al. with planted white ash [13]. Thus planting under successional forest stands, followed in the 3rd growing season by a partial release, increased light availability and growth, at least for a time, and avoided the successional setback and competition problems associated with thinner stands and clearcuts $[12,33,45,51]$.

\subsection{Herbivory}

Apart from some browsing by cottontail rabbit (Sylvilagus floridanus), especially in the early years following planting, and trees crushed by branches or stems of dead trees, we did not observe serious damage other than herbivory by whitetailed deer, especially on red oak (Tab. IV). Red oak suffered more predation than black cherry, but whereas the herbivory level remained unaffected by treatment for the latter species, it more than doubled (in \% of affected trees) for red oaks in control plots, though that was not statistically significant (Tab. IV). Deer behaviour is probably spatially dependent, but we did not detect any block or site effect. These results are important because they go against the accepted opinion that thinning the stand should increase herbivory. We observed no such increase, even in red oak which experienced the most browsing. 
Three studies have reported that decreased stand density, which would have the effect of making planted trees more visible, resulted in greater deer herbivory $[11,18,51]$. For two of these studies, however, that of Gordon et al. [18] and of Truax et al. [51], the determining factor was the understory vegetation, more than the overall openness of the stand. Indeed, in both of these studies the impact of deer browsing was greatest where understory vegetation decreased, but not the density of the upper canopy. Our observations concur; the trees that were the least damaged by deer were often those, wellreleased from above, that were surrounded, but not suppressed, by a vigorous re-growth of understory competition, especially raspberry (Rubus spp.). Those trees had good light conditions at their crown and were possibly better protected from deer. On the other hand, trees under a dense upper canopy are often fairly free of understory competition, and thus paradoxically more accessible to deer. Morgan [41] draws similar conclusions from his study of a heavily browsed woodland in England, where vigorous seedlings could only be found under gaps within dense understory thickets, or near obstacles, where they were protected from deer herbivory. It is also possible that deer are more likely to be active under a dense canopy, where they can hide better, than in thinned stands where they are more vulnerable, especially in areas where hunting is allowed.

Our results support the idea of a dynamic silviculture in young intolerant hardwood stands of moderate height located in sensitive rural landscapes. Under-planting with possibly frequent, light cuts timed with the growth of planted trees can be used to achieve multiple objectives. It seems promising as an economically and ecologically sound alternative management technique for impoverished young stands following agriculture abandonment. We believe that such an approach should allow for the optimal establishment of planted trees initially, followed by sustained growth if regular maintenance is performed, and long term conservation of forest cover and its associated benefits to the landscape.

Acknowledgements: This work was made possible thanks to the financial support of the Direction de la recherche forestière (Forêt Québec - MRNQ), the Agence forestière de la Montérégie and Mr. René Dulude For. Eng., as well as NSERC (grant to A. Bouchard), GREFi (scholarships to A. Paquette) and FQRNT (grant to A. Cogliastro and A. Bouchard). We wish to thank the owners of the sites for their invaluable support over the years. We would also like to thank the many summer students and field assistants who worked on this project. Two anonymous reviewers provided very constructive propositions to improve the manuscript.

\section{REFERENCES}

[1] Ådjers G., Hadengganan S., Kuusipalo J., Nuryanto K., Vesa L., Enrichment planting of dipterocarps in logged-over secondary forests: effect of width, direction and maintenance method of planting line on selected Shorea species, For. Ecol. Manage. 73 (1995) 259-270.

[2] Agestam E., Ekö P.M., Nilsson U., Welander N.T., The effects of shelterwood density and site preparation on natural regeneration of Fagus sylvatica in southern Sweden, For. Ecol. Manage. 176 (2003) 61-73.
[3] Askins R.A., Sustaining biological diversity in early successional communities: the challenge of managing unpopular habitats, Wild. Soc. Bull. 29 (2001) 407-412

[4] Aubin I., Beaudet M., Messier C., Light extinction coefficients specific to the understory vegetation of the southern boreal forest, Quebec, Can. J. For. Res. 30 (2000) 168-177.

[5] Baker D.L., Andelt W.F., Burnham K.P., Shepperd W.D., Effectiveness of Hot Sauce and Deer Away repellents for deterring elk browsing of aspen sprouts, J. Wildl. Manage. 63 (1999) 13271336 .

[6] Bouchard A., Domon G., The transformations of the natural landscapes of the Haut-Saint-Laurent (Québec) and their implications on future resource management, Landsc. Urb. Plann. 37 (1997) 99107.

[7] Boulet-Gercourt B., Lebleu G., Les plantations d'enrichissement : leur utilisation après chablis, Forêt-entreprise 135 (2000) 53-59.

[8] Brandeis T.J., Newton M., Cole E.C., Underplanted conifer seedling survival and growth in thinned Douglas-fir stands, Can. J. For. Res. 31 (2001) 302-312.

[9] Brisson J., Bouchard A., In the past two centuries, human activities have caused major changes in the tree species composition of southern Quebec, Canada, Écoscience 10 (2003) 236-246.

[10] Brooks R.T., Abundance, distribution, trends, and ownership patterns of early-successional forests in the northeastern United States, For. Ecol. Manage. 185 (2003) 65-74.

[11] Buckley D.S., Sharik T.L., Isebrands J.G., Regeneration of northern red oak: positive and negative effects of competitor removal, Ecology 79 (1998) 65-78.

[12] Carnevalea N.J., Montagnini F., Facilitating regeneration of secondary forests with the use of mixed and pure plantations of indigenous tree species, For. Ecol. Manage. 163 (2002) 217-227.

[13] Cogliastro A., Benjamin K., Bouchard A., Effects of full and partial clearing, with and without herbicide, on weed cover, light availability, and establishment success of white ash on shrub communities of abandoned pastureland in southwestern Quebec, Canada, New For. 32 (2006) 197-210

[14] Cogliastro A., Gagnon D., Daigle S., Bouchard A., Improving hardwood afforestation success: an analysis of the effects of soil properties in southwestern Quebec, For. Ecol. Manage. 177 (2003) 347359

[15] Curt T., Coll L., Prévosto B., Balandier P., Kunstler G., Plasticity in growth, biomass allocation and root morphology in beech seedlings as induced by irradiance and herbaceous competition, Ann. For. Sci. 62 (2005) 51-60.

[16] Domon G., Bouchard A., Gariépy M., The dynamics of the forest landscape of Haut-Saint-Laurent (Quebec, Canada): interactions between biophysical factors, perception and policy, Landsc. Urban Plann. 25 (1993) 53-74.

[17] Drever C.R., Lertzman K.P., Effects of a wide gradient of retained tree structure on understory light in coastal Douglas-fir forests, Can. J. For. Res. 33 (2003) 137-146.

[18] Gordon A.M., Simpson J.A., Williams P.A., Six-year response of red oak seedlings planted under a shelterwood in central Ontario, Can. J. For. Res. 25 (1995) 603-613.

[19] Grassi G., Giannini R., Influence of light and competition on crown and shoot morphological parameters of Norway spruce and silver fir saplings, Ann. For. Sci. 62 (2005) 269-274.

[20] Greene D.F., Kneeshaw D.D., Messier C., Lieffers V., Cormier D., Doucet R., Coates K.D., Groot A., Grover G., Calogeropoulos C., Modelling silvicultural alternatives for conifer regeneration in boreal mixedwood stands (aspen/white spruce/balsam fir), For. Chron. 78 (2002) 281-295

[21] Hannah P.R., The shelterwood method in northeastern forest types: a litterature review, North. J. Appl. For. 5 (1988) 70-77. 
[22] Harrington C.A., Forests planted for ecosystem restoration or conservation, New For. 17 (1999) 175-190.

[23] Hix D.M., McNeel C.A., Townsend E.C., Treatments for enhancing early survival and growth of northern red oak seedlings, Tree Planters' Notes 45 (1994) 137-141.

[24] Hooper E., Condit R., Legendre P., Responses of 20 native tree species to reforestation strategies for abandoned farmland in Panama, Ecol. Appl. 12 (2002) 1626-1641.

[25] Hulbert S.H., Pseudoreplication and the design of ecological field experiments, Ecol. Monogr. 54 (1984) 187-211.

[26] Johnson P.S., Responses of planted northern red oak to three overstory treatments, Can. J. For. Res. 14 (1984) 536-542.

[27] Johnson P.S., Dale C.D., Davidson K.R., Planting northern red oak in the Missouri Ozarks: A prescription, North. J. Appl. For. 3 (1986) 66-68.

[28] Kaelke C.M., Kruger E.L., Reich P.B., Trade-offs in seedling survival, growth, and physiology among hardwood species of contrasting successional status along a light-availability gradient, Can. J. For. Res. 31 (2001) 1602-1616.

[29] Kenk G., Guehne S., Management of transformation in central Europe, For. Ecol. Manage. 151 (2001) 107-119.

[30] Kozlowski T.T., Physiological ecology of natural regeneration of harvested and disturbed forest stands: implications for forest management, Can. J. For. Res. 158 (2002) 195-221.

[31] Langvall O., Lofvenius M.O., Effect of shelterwood density on nocturnal near-ground temperature, frost injury risk and budburst date of Norway spruce, For. Ecol. Manage. 168 (2002) 149-161.

[32] Larrick D.S., Bowersox T.W., Storm G.L., Tzilkowski W.M., Artificial oak regeneration in historic woodlots at Gettysburg national military park, North. J. Appl. For. 20 (2003) 131-136.

[33] Lieffers V.J., Stadt K.J., Growth of understorey Picea glauca, Calamagrostis canadensis, and Epilobium angustifolium in relation to overstory light, Can. J. For. Res. 24 (1994) 1193-1198.

[34] Litvaitis J.A., Shrublands and early-successional forests: critical habitats dependant on disturbance in the northeastern United States, For. Ecol. Manage. 185 (2003) 1-4.

[35] Lorimer C.G., Chapman J.W., Lambert W.D., Tall understorey vegetation as a factor in the poor development of oak seedlings beneath mature stands, J. Ecol. 82 (1994) 227-237.

[36] Luginbühl Y., Perception paysagère des espaces en déprise et des boisements spontanés des terres agricoles, Ingénieries (numéro hors série : boisements naturels des espaces agricoles en déprise) (1999) 25-29.

[37] Man R., Lieffers V., Effects of shelterwood and site preparation on microclimate and establishment of white spruce seedlings in a boreal mixedwood forest, For. Chron. 75 (1999) 837-844.
[38] Marquis D.A., Black Cherry (Prunus serotina Ehrh.), in: Burns R.M., Honkala B.H. (Eds.), Silvics of North America, Vol. 2, Hardwoods, USDA Forest Service, Washington, DC,1990, pp. 594604.

[39] Martinez-Garza C., Howe H.F., Restoring tropical diversity: Beating the time tax on species loss, J. Appl. Ecol. 40 (2003) 423429.

[40] Montagnini F., Eibl B., Grance L., Maiocco D., Nozzi D., Enrichment planting in overexploited subtropical forests of the Paranaense region of Misiones, Argentina, For. Ecol. Manage. 99 (1997) 237-246.

[41] Morgan R.K., The role of protective understorey in the regeneration system of a heavily browsed woodland, Vegetatio 92 (1991) 119132.

[42] Paquette A., Bouchard A., Cogliastro A., Survival and growth of under-planted trees: A meta-analysis across four biomes, Ecol. Appl. 16 (2006) 1575-1589.

[43] Parent S., Messier C., A simple and efficient method to estimate microsite light availability under a forest canopy, Can. J. For. Res. 26 (1996) 151-154.

[44] Ricard J.-P., Messier C., Delagrange S., Beaudet M., Do understory sapling respond to both light and below-ground competition? a field experiment in a north-eastern American hardwood forest and a literature review, Ann. For. Sci. 60 (2003) 749-756.

[45] Rose R., Rosner L., Eighth-year response of Douglas-fir seedlings to area of weed control and herbaceous versus woody weed control, Ann. For. Sci. 62 (2005) 481-492.

[46] Sander I.L., Red oak (Ouercus rubra L.), in: Burns R.M., Honkala B.H. (Eds.), Silvics of North America, Vol. 2, Hardwoods, USDA Forest Service, Washington, DC, 1990, pp. 727-733.

[47] Simard H., Bouchard A., The precolonial 19th century forest of the Upper St. Lawrence region of Quebec: a record of its exploitation and transformation through notary deeds of wood sales, Can. J. For. Res. 26 (1996) 1670-1676.

[48] Smidt M.F., Puettmann K.J., Overstory and understory competition affect underplanted eastern white pine, For. Ecol. Manage. 105 (1998) 137-150.

[49] Spetich M.A., Dey D.C., Johnson P.S., Graney D.L., Competitive capacity of Quercus rubra L. planted in Arkansas' Boston Mountains, For. Sci. 48 (2002) 504-517.

[50] Thibault M., Les régions écologiques du Québec méridional, Service de la recherche appliquée, Ministère de l'énergie et des ressources, Québec, 1985.

[51] Truax B., Lambert F., Gagnon D., Herbicide-free plantations of oaks and ashes along a gradient of open to forested mesic environments, For. Ecol. Manage. 137 (2000) 155-169. 